DOI https://doi.org/10.18551/rjoas.2018-08.31

\title{
THE EFFECT OF TAXPAYER UNDERSTANDING ON MSMES TAXPAYER COMPLIANCE
}

\author{
Djatmiko Hary \\ The Supreme Court of the Republic of Indonesia \\ E-mail: harydj@gmail.com
}

\begin{abstract}
The problem concerning the level of taxpayer compliance is one that continues to occur in the field of taxation. In Indonesia itself, the level of taxpayer compliance is still low. Low level of tax compliance in meeting tax obligations is very ironic when compared with the growth of business in Indonesia. MSMEs taxpayers who use simple accounting calculations still not able to compile the accountancy in details. Based on the background of the problems above, the problem of the research can be formulated as follows: "What is the effect of taxpayer understanding on MSMEs taxpayer compliance"? It can be concluded that there is a significant effect of taxpayer understandings on MSMEs tax compliance. This shows that the better the understanding, the better the compliance. If the taxpayers understand the taxation better, their compliance to carry out the obligations will increase. The existence of this significant influence indicates that better understanding of taxpayers will affect the improvement of taxpayer compliance.
\end{abstract}

\section{KEY WORDS}

Taxpayers, tax compliance, MSMEs, Indonesia.

A country uses tax revenue to sustain its development financing. Tax revenue is expected to continue to increase so that the development of the country can run well. Increased tax revenue can be achieved if there is an increase in the number of taxpayers. The efforts to maximize tax revenue cannot only rely on the role of the Directorate General of Taxes or tax officers but also the active role of the taxpayers themselves (Huda, 2015).

Given the importance of the role of taxes, the government which in this case is the Directorate General of Taxes has made various efforts to maximize tax revenues. Recognizing the role of taxes to drive the government and state development, since 1983, there have been some efforts carried out in the form of continuous national tax system reform (Ekawati, 2008). One of the efforts is made through the reform of the legislation in the field of taxation with the enactment of Self-Assessment System. The Self-Assessment System requires taxpayers to register, calculate, pay, and report on their own amount of tax owing to their obligations (Utami et al., 2012).

However, the growth of tax revenue has not achieved the expected results. This is evidenced by the low tax ratio in Indonesia. The factors that cause this low tax ratio are low income per capita, low level of taxpayer compliance, as well as the non-transparent report of business circulation and income did by taxpayers. The low public awareness of tax obligations is often caused by public ignorance of the taxation rules (Yadnyana and Sudiksa, 2011).

One effort made by the government to increase tax revenue is the provision of extensification activities. What is meant by extensification activity related to revenue target (extra effort) is the increase in the number of taxpayers. With the expansion of the number of taxpayers, it is expected to increase tax revenue. The National Tax Census (Sensus Pajak Nasional or SPN) is an activity from the Directorate General of Taxes (DGT) intended to expand the number of taxpayers to achieve and secure tax revenue targets (Yusro and Kiswanto, 2014).

The problem with the level of taxpayer compliance is a problem that continues to occur in the field of taxation. In Indonesia itself, the level of taxpayer compliance is still low. The level of taxpayer compliance to fulfill its tax obligations is still very ironic when compared to the level of business growth in Indonesia (Yusro and Kiswanto, 2014).

The growth in the number of Micro, Small, and Medium Enterprises (MSMEs) has increased from year to year. However, the increase in this field was not balanced by the 
awareness of MSMEs owners to perform their tax obligations. In Indonesia, the number of MSMEs has increased from year to year in which is evidenced by the number of units of MSMEs (Yusro and Kiswanto, 2014).

According to the data from the Ministry of Cooperatives and SMEs, the total number of MSMEs from 2011 to 2012 reached 1,328,147 units and contributed $99.9 \%$ to the business structure in Indonesia. Nevertheless, these improvements and contributions were not matched by an increase in compliance and contribution of MSMEs owners in fulfilling their tax obligations.

This is what encourages the Government to issue the latest regulation that is Government Regulation Number 46 of 2013 concerning the treatment of income tax for Micro, Small, and Medium Enterprises where individual taxpayers (Wajib Pajak Orang Pribadi or WP OP) or corporate taxpayers (Wajib Pajak Badan or WP Badan) not including Permanent Business (Bentuk Usaha Tetap or BUT) and taxpayers who do free work, are subject to Final Income Tax and required to pay taxes at a rate of $1 \%$ of the gross circulation each month on income from its business (Marista and Fajriana, 2014).

Seen from the compliance of MSMEs taxpayer, according to Resyniar (2013), there are still many shortcomings in every aspect. Many MSMEs taxpayers do not report and pay taxes deliberately due to a number of things such as the regulations that are difficult to understand. MSMEs taxpayers who still use simple accounting calculations have not been able to compile their accountancy in detail. This is also a factor that weakens the level of taxpayer compliance, especially for MSMEs owners.

Wibowo (2004) added that MSMEs also has some weaknesses such as market uncertainty, the uncertainty of survival in the first year of business, unclear bookkeeping (accountancy), and lack of tax regulations understanding. These weaknesses usually affect the understanding and obligations of each MSMEs owner to fulfill its tax obligations.

According to Burton (2009: 17), the lack of awareness of taxpayers in paying taxes occurs due to the public's thought that tax is basically a government robbery. This kind of pressure continues to infiltrate their mind. It also happens because the results of paying taxes are not visible and the rules are assumed difficult.

Many entrepreneurs of MSMEs do not have a Tax ID Number (Nomor Pokok Wajib Pajak or NPWP). This is because taxes are still considered frightening and can endanger their business. Most MSMEs also do not have irregular accountancy which makes tax audits become difficult (Thoriq, 2015). Based on the background of the problems above, the problem of the research can be formulated as follows: "What is the effect of taxpayer understanding on MSMEs taxpayer compliance"? In accordance with the background and previous problems, this research is expected to answer and uncover the problems through discussion that is easy to understand and well directed. To realize all of that, there is a goal in this research that is "To analyze the effect of taxpayer understanding on MSME taxpayer compliance".

Taxpayer Compliance. In Indonesian Dictionary, compliance means conforming or obeying the teachings or rules. Compliance is the motivation of a person, group, or organization to act according to the rules. Tax compliance is a person's obedience which in this case is a taxpayer to the tax regulations or laws (Tiraada, 2013). Compliance is the motivation of a group or organization to do or not act according to the rules that have been established (Saraswati, 2012). Compliance that is formed in the environment is formed from interactions between individuals, groups, and organizations.

Utami et al., (2012) explained that taxpayer compliance is a taxpayer stipulated by the Directorate General of Taxes as a taxpayer who meets certain criteria that can be given a preliminary return on tax overpayment. According to Rustianingsih (2011), tax compliance is defined as a condition in which taxpayers obey and have awareness of fulfilling their awareness. On the other hand, Supadmi (2006) in Rustianingsih (2011) said that obeying tax obligations with awareness and fulfillment is reflected in the following situations: Taxpayers understand and try to comprehend all taxation legislation; Taxpayers fill out the tax form completely and clearly; Taxpayers calculate the amount of tax owed correctly; Taxpayers pay the taxes on time.

Taxpayer compliance can be measured by using indicators that are in line with the criteria of obedient taxpayers including understanding the tax law, filling out the tax return 
correctly, calculating the taxes correctly, paying the taxes on time, and do not have tax arrears (Arum, 2012). Taxpayer compliance according to Rahayu (2012: 138) is defined as "a condition where taxpayers fulfill all tax obligations in terms of carrying out their taxation rights".

Muliari and Setiawan (2011) described tax compliance as a condition in which taxpayers fulfill all tax obligations and carry out their taxation rights so that the context of compliance in this study means that taxpayers try to comply the applicable tax laws, whether fulfilling the obligations or exercising the taxation rights. Obedient taxpayers are those who fulfill and implement tax obligations in accordance with the provisions of tax laws and regulations (Rahayu, 2012: 138).

Nasucha (2004: 111) believed that the notion of taxpayer compliance is guilt and shame and the perception of taxpayers on the fairness and equity of the tax burden they bear as well as the influence of satisfaction on government services. Meanwhile, Nurmantu (2003) proposed that tax compliance is a condition where taxpayers fulfill all tax obligations and carry out their taxation rights.

In general, compliance is divided into two, namely: formal compliance and material compliance. Formal compliance reflects the fulfillment of deposit and tax reporting obligations in accordance with the prescribed schedule while material compliance emphasizes the substantive aspects of the number of tax payments in accordance with the provisions or regulations (Hutagaol, 2007: 307).

Zain (2008: 31) asserted that taxpayer compliance is a climate of compliance and awareness of tax obligations fulfillment reflected in situations where taxpayers understand or seek to understand all the provisions of tax legislation, fill out tax forms completely and clearly, calculate the taxes correctly, and pay and report the tax owed on time.

According to the Regulation of Minister of Finance number 192/PMK.03/2007, the criteria for obedient taxpayers are: First, on time on the submission of Letter of Notification (Surat Pemberitahuan or SPT) including: the submission of annual notification within the last 3 (three) years on time, the submission of late SPT for the last period from January to November that is not consecutive and not more than 3 tax periods for each type of tax, late SPT as referred to in letter $b$ has been submitted without passing the deadline for submitting the SPT for the next tax period. Second, do not have tax arrears for all types of taxes unless they have obtained a license to pay in installments or postpone payment of taxes including the circumstances on December 31 before determined as a compliant taxpayer which does not include tax debt before passing the deadline. Third, financial statements are audited by public accountants or government financial supervision institutions with unqualified opinions for three consecutive years with a long-form report. There is also a reconciliation of commercial and fiscal profit and loss for taxpayers who submit Annual SPT as well as the accountant's opinion on the audited financial statements that is signed by a public accountant who is not in the team of government financial supervision institutions. Fourth, never been sentenced for committing a criminal act in the field of taxation based on a court decision that has permanent legal force within the last 5 years.

Taxpayer Understanding. Understanding is something we know and comprehend correctly. It is how a person maintains, differentiates, suspects, explains, expands, concludes, generalizes, gives examples, rewrites, and warns something (Arikunto, 2009: 118). Taxpayer understanding can also be interpreted as the view of taxpayers on the tax knowledge they have.

According to Riko (2006: 75), the level of understanding is an intensive process of increasing knowledge by an individual and to what extent he will be able to properly understand the material of the problem he wants to know. Whereas, Muslims (2007: 11) argued that the higher the level of taxpayers' knowledge and understanding of taxation regulations, the less likely the taxpayer is to violate these regulations thereby increasing the level of taxpayer compliance.

Mardiasmo (2011: 23) asserted that taxpayers are individuals or entities including tax payments, tax deductions, and tax collection that have tax rights and obligations in accordance with the provisions of the taxation legislation. The understanding of taxpayer on taxation regulations is a taxpayer's way of knowing and understanding tax regulations. 
Taxpayers will tend not to be obedient when they do not understand tax regulations (Julianti, 2014: 30).

Taxation understanding consists of filling out the SPT well and smoothly. In this case, there must be an understanding related to SPT fulfillment, the amount of owed taxes which can be calculated in accordance with the provisions of taxation, payment, and timely submission. Also, there must be a report on the amount of taxes to the registered taxpayers (Ekawati, 2008: 2). The level of understanding of taxpayers on taxation can be measured based on their understanding of the obligation to calculate, pay and report the payable taxes (Lestari, 2010). The higher the level of knowledge and understanding of taxpayers on taxation regulations, the less likely the taxpayer to violate the regulations so as to increase taxpayer compliance.

Taxpayer understanding is all things about taxation that are well understood and considered true by taxpayers. Taxpayers should have an understanding of taxation, especially in regard to the importance of taxes for state financing because the behavior of the taxpayer is based on their views on taxes. Furthermore, related to the fulfillment of tax rights and obligations, the understanding of taxation is expected to encourage taxpayer awareness to fulfill their tax obligations (Putri, 2014).

\section{METHODS OF RESEARCH}

This study uses quantitative research emphasizing the testing of theories through the measurement of research variables with numbers and data analysis with statistical procedures (Indriantoro and Supomo, 2002: 12).

The population in this study is all MSMEs taxpayers. The number of furniture MSMEs is 356 units approximately. The instrument used in this study is questionnaires. Questionnaires are an efficient data collection technique that is suitable to be used if the number of respondents is large and spread over a wide area. The questionnaires can be in the form of closed and open questions or statements. It can be given to respondents directly or sent by post or by the internet (Sugiyono, 2012: 199).

After the researcher obtains the data, it will be brought to be processed or analyzed to re-examine the validity of the data and, at the same time, to make a source criticism with a comparative method to compare the two legal systems of granting property to adopted children. Then, the interpretation of the meaning of the words and sentences will be concluded deductively and then reported descriptively.

\section{RESULTS AND DISCUSSION}

Based on the results of the research, the variable of taxpayer understanding (X1) obtained the value of t-count by 2.209 and $p$-value by 0.031 . Therefore, the comparison of tcount to t-table is $2.209>2.0003$ and the comparison of $p$-value to alpha is $0.031<0.05$. The results of the comparison show that the t-count is greater than t-table and the p-value is smaller than $\alpha$ thereby $\mathrm{H} 1$ is accepted. By that, there is a significant effect between the understanding of taxpayers on the compliance of MSMEs taxpayers. This shows that the better understanding of taxpayers, the better the taxpayer compliance. Taxpayers understanding is an important factor that needs to be considered by taxpayers. The more they understand taxation, they will have a better compliance in carrying out their obligations. The existence of this significant influence indicates that better understanding of taxpayers will have an effect on increasing taxpayer compliance. Empirically, the level of MSMEs taxpayer understanding in the field is quite good. Respondents understand well taxation regulations and tax concepts so that they understand the advantages and disadvantages of not having an obedient behavior in taxation. Therefore, by increasing the taxation understanding, taxpayer compliance will also increase. The results of this study support the research results from Putri (2013) showing that the understanding of taxpayers influences MSMEs taxpayer compliance. Marista, Betri, and Fajriana (2014) also pointed out that taxpayer understanding has a significant effect on MSMEs taxpayer compliance. Besides that, Pravitasari, Radianto, and Upa (2012) wrote that there is a significant influence of taxpayer understanding on taxpayer compliance. 


\section{CONCLUSION}

Based on the description of the results and discussion above, it can be concluded that: The first hypothesis testing shows that the variable of taxpayer understanding generated a tcount by 2.209. Due to the value of $t$-count that is greater than t-table $(2.209>2.0003)$ with a probability of $0.031<0.05$, it can be said that $\mathrm{H} 1$ is accepted. This means that the understanding of taxpayers has a significant positive effect on MSMEs taxpayer compliance. Therefore, it is suggested that MSMEs taxpayers can be more sensitive and active towards the existing tax regulations and able to have a role for the next tax regulations.

\section{REFERENCES}

1. Arum, H.P.(2012). Pengaruh kesadaran wajib pajak, pelayanan fiskus, dan sanksi pajak terhadap kepatuhan wajib pajak orang pribadi yang melakukan kegiatan usaha dan pekerjaan bebas. Diponegoro Journal of Accounting. Vol.1 No.1.

2. Atawodi, O.W \& Stephen, A.O. (2012). Factors that tax compliance among small and medium enterprise (SMEs) in Nort Central Nigeria. Internasional Journal og Bussiness and Management, Vol. 7 No. 12. P.87-96 Nigeria: Covenant University.

3. Burton, R. (2009). Kajian aktual perpajakan. Jakarta : Salemba Empat.

4. Ekawati. (2008). Survey pemahaman dan kepatuhan wajib pajak usaha kecil dan menengah di kota Yogyakarta. Jurnal Teknologi dan Manajemen Informatika. Volume 6, September 2008.

5. Ghozali, I. (2011). Aplikasi analisis multivariate dengan program IBM SPSS19. Semarang: Badan Penerbit Universitas Diponegoro.

6. Gujarati, D.N \& Porter, D.C. (2010). Dasar-dasar Ekonometrika. Jakarta: Salemba Empat.

7. Hardiningsih, P \& Yulianawati, N. (2011). Faktor-faktor yang mempengaruhi kemauan membayar pajak. Jurnal Dinamika Keuangan dan Perbankan, Vol. 3, No. 1, p.126-147.

8. Haryo, S.K. (2003). Pengaruh perubahan tarif pajak penghasilan perorangan pada Undang-UndangNo.17 Tahun 2000 dibandingkan dengan Undang-Undang No. 7 Tahun 1983 dalam kaitan terhadap kepatuhan wajib pajak untuk membayar pajak di kota Banjarmasin. Unpublished Thesis. Universitas Diponegoro.

9. Huda, A. (2015). Pengaruh persepsi atas efektifitas sistem perpajakan, kepercayaan, tarif pajak, dan kemanfaatan NPWP terhadap kepatuhan membayar pajak (studi empiris pada wajib pajak UMKM makanan di KPP Pratama Pekanbaru Senapelan. Jom FEKOM, Vol.2, No.2. October 2015.

10. Hutagaol, J. (2007). Perpajakan isu-isu kontemporer. Jakarta: Salemba Empat.

11. Indriantoro, N \& Supomo, B. (2002). Metodologi penelitian bisnis. Yogyakarta : BPFE Yogyakarta.

12. Judisseno, R. K. (2005). Pajak dan strategi bisnis. Jakarta: Gramedia Pustaka Umum.

13. Julianti, M. (2014). Analisis faktor-faktor yang mempengaruhi kepatuhan wajib pajak orang pribadi untuk membayar pajak dengan kondisi keuangan dan preferensi risiko wajib pajak sebagai variabel moderating. Unpublished Thesis. Universitas Diponegoro.

14. Lestari, P. (2010). Analisis tingkat pemahaman terhadap pelaksanaan self assessment system. Media Keuangan, Vol. 2, No. 17.

15. Lusty. (2012). Pemahaman akuntansi dan kesadaran membayar pajak terhadap kepatuhan wajib pajak UMKM di kota Yogyakarta. Unpublished Thesis. Universitas Pembangunan Veteran Yogyakarta.

16. Mardiasmo. (2011). Perpajakan. Yogyakarta: CV Andi Offset.

17. Marista, M. B. \& Fajriana, I. (2014). Pengaruh pemahaman wajib pajak UMKM terhadap pelaksanaan Peraturan Pemerintah No. 46 Tahun 2013 (studi empiris wajib pajak UMKM yang terdaftar di KPP Pratama Palembang Ilir Barat). Jurnal Ekonomi. STIE Multi Data Palembang. 